\title{
The androgen receptor and prostate cancer: A role for sexual selection and sexual conflict?
}

\author{
Kyle Summers $^{a, *}$, Bernard Crespi ${ }^{b}$ \\ a Department of Biology, East Carolina University, Greenville, NC 27858, USA \\ b Department of Biological Sciences, Simon Fraser University, Burnaby, BC, Canada V5A 156
}

Received 6 April 2007; accepted 16 April 2007

\begin{abstract}
Summary We propose and evaluate the hypothesis that the CAG repeat region of the androgen receptor represents a locus of antagonistic pleiotropy in the context of sexual selection and sexual conflict. Short repeats are associated with increased transactivation of the androgen receptor at the molecular level, and increased fertility at the phenotypic level. However, short repeats are also associated with increased risk of prostate cancer, and with more aggressive forms of the disease. The somatic evolution of cancer cell lineages also shows a repeated pattern of shortening of the CAG repeat in association with cancer progression, apparently as a result of positive selection among cell lineages. We further postulate that other genes associated with prostate cancer are likely to mediate antagonistic pleiotropy in the context of sexual selection and sexual conflict. A key prediction of this hypothesis is that the genes mediating antagonistic pleiotropy will show historical evidence of positive selection, particularly in the context of sexual conflict. Previous research on the molecular evolution of specific genes associated with prostate cancer supports this prediction, and we suggest further critical tests of the role for genomic conflicts and tradeoffs in the evolution of cancer risk.
\end{abstract}

(c) 2007 Elsevier Ltd. All rights reserved.

\section{Introduction}

Sexual selection and sexual conflict are topics of central interest in evolutionary biology [1]. The study of sexual selection focuses on a wide variety of traits selected in the context of mating, with emphasis on competition for mates and selectivity about mating [1]. Sexual selection can favor traits that enhance reproductive success early in life at the expense of reduced survivorship later in life - that is, antagonistic pleiotropy $[2,3]$.

\footnotetext{
* Corresponding author. Tel.: +1 2523286304.

E-mail address: summersk@ecu.edu (K. Summers).
}

Genes that cause such antagonistic pleiotropy in the context of sexual selection may also drive sexual conflict. Sexual conflict exists when aspects of male behavior, physiology or other phenotypic traits enhance male reproductive fitness but impose a cost on the fitness of females, or vice versa [4]. Sexual conflict can occur in several different ways, including intragenomic conflict, intergenomic (or interlocus) conflict, and intersexual ontogenetic conflict [4,5]. Recent evidence suggests that these forms of genetic conflict are common $[5,6]$.

In this paper, we hypothesize that the androgen receptor represents an example of antagonistic 
pleiotropy in the context of sexual selection and possibly sexual conflict. Specifically, we propose that the CAG repeat of the androgen receptor represents a locus of antagonistic pleiotropy within the androgen receptor gene. We begin with a general review of the connections between sexual selection, androgens and the prostate gland, and then focus on the androgen receptor in particular. We then discuss the possibility that other genes associated with prostate cancer also mediate antagonistic pleiotropy in the context of sexual selection and sexual conflict.

The prostate gland and seminal vesicles produce seminal fluid in mammalian males [7]. Hence, the prostate constitutes a critical locus for the interaction of steroid hormones and seminal fluid proteins. These processes are crucial to male reproduction in a variety of ways, such as potential mating rate and sperm competition [8]. In male Drosophila, seminal proteins mediate sexual conflict by promoting fertility and preventing remating, but at the expense of female survivorship [9]. A number of seminal proteins in Drosophila, such as the accessory gland protein Acp26Aa, have been shown to exhibit rapid evolution and high ratios of non-synonymous to synonymous substitution, a hallmark of positive selection [10]. In mammals in general [11] and primates in particular [12], seminal proteins have been found to evolve rapidly and show evidence of positive selection related to sexual selection and sexual conflict. Sexual selection and sexual conflict are thus expected to act on the proteins that make up this locus of interaction.

\section{Steroid hormones, the androgen receptor, and cancer}

The development and expression of many key aspects of morphology and physiology influenced by sexual selection are mediated by steroid hormones [8]. These hormones, particularly androgens, may be subject to sexual selection and sexually antagonistic evolution in their pathways of signaling and reception. For example, testosterone, which is secreted by the testis, is well known as a major hormonal regulator of diverse aspects of male morphology, physiology and behavior subject to sexual selection [13]. Testosterone is also critically involved in the production of seminal fluid, which appears to be strongly influenced by sexual selection and sexual conflict [14].

Many steroid hormones and associated proteins are likely to exhibit antagonistic pleiotropy within males, with beneficial effects on reproduction early but negative effects on survivorship later in life [8]. For example, high androgen levels are associated with high reproductive effort and mating success at early life history stages in a variety of species (reviewed in [8]), but they are also associated with reduced survivorship in later life (e.g. [15]). In humans, increased androgen levels are associated with increased risk of prostate cancer [16], among other costs [17]. Steroid hormones and associated proteins are also likely to mediate various forms of sexual antagonism, given that selection is expected to favor functions conducive to early reproduction but harmful to long-term survival more strongly in males than in females [2]. In turn, diverse molecular-genetic and clinical evidence indicates that this type of sexual antagonism, and consequent sexually antagonistic coevolution generates pleiotropic genetic effects that enhance the risk of cancer [18].

The androgen receptor gene $(A R)$ plays a central role in prostate cancer occurrence and progression [19]. The genes AR, CYP17, SRD5A2, HSD3B1 and HSD $3 B 2$ are all intimately involved in androgen metabolism and cell proliferation in the prostate [21]. Each shows intraspecific polymorphism and variation among racial-ethnic groups that is associated with the risk of prostate cancer [21].

The $A R$ binds testosterone and regulates the transcription of androgen-responsive genes, many of which stimulate cellular replication and tissue growth $[20,21]$. Because the $A R$ mediates the effects of testosterone, it is intimately involved in the development of secondary sexual characteristics [22]. Hence, this receptor is an important locus for the action of sexual selection, and it influences many aspects of male display and male competitive ability in species subject to strong sexual selection on males.

The increased levels of cell proliferation stimulated by steroid hormones like testosterone on target organs are associated with increased frequency and aggressiveness of cancer [23]. Indeed, eunuchs and men with under-developed prostates seldom or never develop prostate cancer [20]. In a prospective study, Gann et al. [24] found that circulating levels of testosterone predict the development of prostate cancer. Virtually all cases of prostate cancer involve somatic mutations in the androgen receptor, and strategies of therapy for this disease focus overwhelmingly on reducing or eliminating the binding of the androgen receptor to testosterone (or substitute ligands), or the binding of the androgen receptor to DNA and its subsequent stimulation of expression [19].

For the androgen receptor gene, the $\mathrm{N}$-terminal domain is known to exhibit a form of genetic variation associated with cancer risk in several 
different contexts: a series of microsatellite CAG repeats [25]. Human racial groups differ on average in the number of CAG repeats, and these differences are associated with variation in prostate cancer occurrence and rate of progression [20]. Within populations, smaller numbers of repeats are linked to increased risk of prostate cancer [26]. A recent meta-analysis of previous studies concluded that the effects of repeat length on prostate cancer are small but statistically significant [27]. Within individuals, the progression of prostate cancer is associated with reduced repeat length due to the somatic evolution of cancer cell lineages [28]. Across species, CAG repeat number has apparently increased along the lineage leading from basal primates to humans [29], which suggests that repeat length increases with lifespan across primates. Repeat length has been demonstrated to have a negative correlation with transactivation function $[25,30]$, which is apparently due to a negative effect of repeat length on p160-mediated coactivation [31]. Recently, transgenic manipulations of CAG repeat length in a mouse model has experimentally demonstrated a negative correlation between repeat length and prostate cancer risk [32].

A substantial body of research indicates that increased CAG repeat length is associated with infertility, low rates of spermatogenesis and hypoandrogenicity, or reduced expression of male-specific traits (e.g. [33]), although not all studies support this association (e.g. [34]). There is also an inverse correlation between CAG repeat length and androgenicity (e.g. [35]). Decreased repeat length is associated with increased production of prostate specific antigen and increased sperm count in adolescent males $[36,37]$. Hence, repeat length for the CAG repeat region may evolve under a tradeoff between sexual selection (favoring decreased length and increased activity) and natural selection (favoring increased length and reduced risk of prostate cancer).

The androgen receptor, as a critical mediator of diverse physiological and morphological effects favored by sexual selection in males, may also represent a focal point of sexually antagonistic coevolution between males and females. Genes expressed in females should be selected to minimize the risks of cancer and other negative effects resulting from excess testosterone and $A R$ activation, whereas male genomes should be selected to tolerate higher levels of testosterone and $A R$ activation (and associated risks of cancer) in the interest of enhanced reproduction. Although women do not develop prostate tissue, the androgen receptor is expressed in a variety of tissues in females, and its expression levels appear to be linked to some kinds of cancer.

Ovarian cancer is the sixth most common cancer in women worldwide [38]. The $A R$ is expressed in primates (including humans) throughout the reproductive cycle, where it modulates follicular growth and maturation and other reproductive processes [39]. $A R$ expression is also found in a very high proportion (up to $95 \%$ ) of tumor tissue samples from ovarian cancers, and frequency of expression positively correlates with malignancy $[40,41]$.

A variety of studies have linked androgens to ovarian cancer [42]. Androgens increase cell proliferation and decrease cell death in ovarian tissue, indicating a cancer-promoting effect [43]. Women with elevated serum levels of androgens have an increased risk of ovarian cancer [44,45], and androgen administration is associated with ovarian cancer in animal models [46]. Ovarian cancer is associated with an increase in androgen production [47]. A coactivator of the AR (AR-associated protein 70, or ARA70) has been found to be up-regulated in ovarian tumors [48]. Recent research suggests that up-regulation of ARA70 is associated with cellular resistance to a specific tumor inhibitor (TGF- $\alpha$ ), and hence to enhanced probability of malignancy [49].

Evidence linking ovarian cancer to polymorphisms in $A R$ expression has been mixed [38]. Several studies have found that shortened repeat length in the CAG repeat region (associated with increased expression of $A R$-activated genes) is associated with reduced age of incidence (e.g. [50]) and increased aggressiveness of ovarian cancer [51]. However, other studies have found no association between repeat length and ovarian cancer (e.g. [52]), and one study found a positive association [53].

There are also links between $A R$ repeat polymorphism and breast cancer. Several studies have found evidence of increased risk for breast cancer with larger CAG repeat size (e.g. [54,55]). By contrast, some studies have not confirmed this relationship (e.g. [56,57]), and Yu et al. [58] found a negative correlation between CAG repeat length and tumor aggressiveness in breast cancer. There is also evidence that CAG repeats evolve through selection in the somatic evolution of colon cancer [59], which indicates that shorter repeat length, may be associated with other forms of cancer as well.

Taken together, the available evidence suggests that expression of the $A R$ influences the risk of a variety of cancers, and that males and females may be selected in opposite directions for $A R$ expression (possibly mediated in part by CAG 
repeat length), resulting in sexual conflict over expression. Indeed, such conflict likely represents only one of many manifestations of sexual conflict over the regulation of hormonal systems, given the myriad pleiotropic effects of testosterone, estrogen and other hormones on physiological systems. While it might appear that females could evolve to optimize their sex-specific expression of the $A R$ in the context of cancer risk, such changes may interfere with important aspects of female physiology [39], and recent evidence also suggests that repression of sexually antagonistic genes is often incomplete or unsuccessful. Indeed, research on Drosophila and other species indicates that the expression of sexually antagonistic genes in the "wrong" sex is pervasive and imposes a significant cost on adults [5,60].

\section{Review of previous research}

If sexual selection and sexual antagonism are generally associated with an increased risk of cancer, then we would expect to find evidence that a variety of genes specifically associated with sexual reproduction would be both implicated in cancer risk and show evidence of positive selection, which is frequently associated with sexual selection, and with antagonistic coevolution [18] (Table 1). A signal of positive selection in comparative analyses of DNA sequences occurs when the ratio non-synonymous to synonymous substitutions exceeds one for all of part of a particular gene [61]. Recently, Clark and Swanson [14] tested for selection on seminal fluid proteins from a variety of primate species. They found evidence for strong positive selection on a number of genes associated with prostate cancer (in terms of heritable variants associated with prostate cancer risk, or associated with gene expression during the progression of prostate cancer, or both). These genes include Kallikrein 2 (KLK2), prostate specific antigen (PSA or $K L K 3)$, prostate acid phosphatase (ACPP), microseminoprotein (PSP94 or MSMB), gastrin-releasing peptide (GRP), prolactin-induced protein (PIP), and transmembrane protease serine 2 (TMPRSS2), transglutaminase 4 (TGM4), and diazapim binding inhibitor $(D B I)$. Many of these genes are associated with other forms of cancer as well, as expected under the antagonistic pleiotropy predicted by our hypothesis.

Kallikrein 2 and prostate specific antigen are members of a family of serine proteases. This gene family shows diverse patterns of evolution, with different species containing different numbers and combinations of loci [62]. Kallikrein 2 and PSA may be restricted to humans and dogs, which is interesting given the notably-high prevalence of prostate cancer in these two species [63]. Both of these genes are under androgen control and have been implicated as important loci involved in prostate cancer [64,65]. Kallikrein 2 expression is elevated in prostate cancer $[64,65]$, and recent evidence connects polymorphism at this locus to increased risk of prostate cancer [66]. Prostate specific antigen (in combination with KLK4) may increase tumor cell migration, specifically in association with prostate cancer [67], although it may act as a tumor suppressor in other contexts [68]. Kallikreins are also involved in a variety of other cancers, and can promote tumor invasion and metastasis [68]. Clark and Swanson [14] used maximum likelihood methods [69] to show that positive

Table 1 Genes expressed in the prostate in association with the production of seminal fluid that are also associated with cancer

\begin{tabular}{|c|c|c|}
\hline Locus & Evidence for selection $(\omega>1)$ & Association with cancer (References) \\
\hline KLK2 & Ref. [14] & $\begin{array}{l}\text { Elevated expression in prostate cancer }[64,65] \\
\text { Increased risk of prostate cancer }[66]\end{array}$ \\
\hline PSA & Ref. [14] & Enhance tumor cell migration [67] \\
\hline$A C P P$ & Ref. [14] & Elevated expression in prostate cancer [78] \\
\hline PSP94 & Ref. [14] & Tumor suppressing function [74-76] \\
\hline GRP & Ref. [14] & Promotes tumor growth \\
\hline PIP & Ref. [14] & Elevated expression in prostate cancer [79] \\
\hline TMPRSS2 & Ref. [14] & $\begin{array}{l}\text { Overexpression in prostate cancer [70] } \\
\text { Implicated in hereditary prostate cancer [71] }\end{array}$ \\
\hline TGM4 & Ref. [14] & Loss associated with prostate cancer progression \\
\hline$D B I$ & Ref. [14] & Elevated expression in prostate, brain and liver cancer [80-82] \\
\hline$S R C-1$ & Ref. [83] & Promotes prostate cancer cell growth [87] \\
\hline ELAC2 & Ref. [83] & Hereditary prostate cancer risk [88] \\
\hline CDC37 & Ref. [83] & Enhances cell proliferation, increases cell survival [84] \\
\hline MTA1 & Ref. [83] & Elevated expression in prostate cancer [85] \\
\hline
\end{tabular}


selection has affected subsets of codons within both KLK2 and PSA. These authors also showed that specific codons identified as being affected by positive selection (via Bayesian inference) were non-randomly associated with the functional (catalytic) sites of this gene based on structural analysis. In sum, these results are consistent with the hypothesis that KLK2 and PSA are positively selected in the context of sexually antagonistic coevolution, with the functional roles of the genes being of general importance to both the risk and somatic evolution of cancer.

Transmembrane protease serine 2 has been identified as an important gene in the development of prostate cancer, with overexpression in neoplastic prostate epithelium [70]. The serine protease domain of TMPRSS2 is released into the extracellular fluid, and interacts there with a G-coupled receptor (PAR-2), which contributes to tumor metastasis. The TMPRSS2 protein is androgen responsive and drives the increased expression of two transcription factors (ERG and ETV1) that are highly expressed in prostate cancer. TMPRSS2 has also been implicated as a candidate gene for some cases of hereditary prostate cancer, although this hypothesis requires further investigation [71]. Hence, for TMPRSS2, beyond the general contribution of this gene to the somatic evolution of cancer, specific alleles of this gene may be particularly likely to promote cancer, and hence are associated with hereditary prostate cancer.

Prostatic secretory protein of 94 amino acids (PSP94, also known as beta microseminoprotein) is a short polypeptide that is a major secretory protein of the prostate in human and other mammals and is abundant in semen. This protein has local functions in the reproductive tract as well as systemic functions [72]. PSP94 is also normally expressed in human female reproductive tissue (e.g. ovarian and breast tissue), as revealed by analysis of representative cancer cell lines [73]. In vivo studies indicate that this protein can function as a tumor suppressor [74], and recently the amino acid motif within PSP94 that is required for tumor suppressor function has been identified [75]. Expression of PSP94 is reduced in cancerous prostate tissues in the rat [76]. Expression analysis using microarrays has revealed a negative association between the expression of PSP94 and prostate cancer [77]. In the case of PSP94, selection in the context of sexual antagonism may focus on mutations that reduce its effectiveness as a tumor suppressor, if these mutations provide some advantage in terms of male reproductive function.

Human prostatic acid phosphatase (ACPP) has been used as a diagnostic marker for prostate can- cer. This gene has been found to exhibit elevated expression in neoplastic prostate tissue, relative to normal tissue [78]. Prolactin-inducible protein $(P I P)$ is another protein expressed in seminal fluid (among other fluids) that has been linked to prostate cancer. This gene is highly expressed in prostate carcinoma relative to benign tissue [79]. Diazapim binding inhibitor shows androgen-regulated patterns of expression and is highly expressed in prostate cancer cell-lines in vitro [80]. This gene has been implicated in both brain tumor formation [81] and hepatocellular carcinoma [82].

Other researchers have also found evidence that genes with prostate-specific normal expression have been subject to positive selection and are also associated with prostate cancer in the context of enhanced expression during somatic evolution, or in the context of allelic variation (heritable prostate cancer risk). Clark et al. [83] found that the genes SRC-1, CDC37, ELAC2, and MTA1 are under positive selection, and these genes are also upregulated in prostate cancer [84-87]. ELAC2 is one of the classic loci associated with hereditary prostate cancer risk [88]. Other genes in this dataset that are upregulated during prostate cancer progression include KNTC1, CDKN3, PPP3CB, JUNB, FOSB, $H M M R, B A P X 1, G N G 11$ and CDKN1B. Several of these genes are known to have functional role associated with growth and replication, such as FOSB (a transcription factor involved in control of the cell cycle). This association with growth and replication also applies to a tumor suppressor gene, LATS1 [89], and the insulin-like growth factor 1 receptor [90]. The expression of one of these genes, CDC37, is mediated by the gene HSP90 [91], which is intimately involved in carcinogenesis [92] and has evolved under positive selection in some mammals [93].

\section{Discussion}

Our hypothesis concerning sexual selection, sexual antagonism and the $A R$ could be more extensively and specifically evaluated via analysis of the joint phylogenetic changes in sexual dimorphism, sexual selection intensity, and measures of $A R$ activation function in males and females, and by using an evolutionary framework to further evaluate the causal links between CAG repeat length, $A R$ activation, cancer risks in males and females, and components of fitness other than disease. Our more general hypothesis that multiple genes critically involved in both sexual selection or sexual conflict are prone to increase the risk of cancer predicts that genes that have the strongest connection to sexual 
selection and sexual antagonism will be the most likely to increase the risk of cancer. Detailed investigations of the mechanisms relating specific genes to effects relevant to both sexual selection and sexual conflict and to cancer risk will be especially useful in testing this hypothesis. It will also be important to expand the size of the datasets used for comparative analyses of positive selection as the number of species sequenced for specific genes increases, and to use other methods of detecting positive selection.

One potential objection to the hypothesis that sexually antagonistic coevolution of reproductive genes increases cancer risk might be that the pleiotropic effects of the genes associated with male reproductive function on cancer risk in females are likely to occur after the child-bearing years of most women affected by cancer. While this demographic pattern is evident, the idea that selection will not act against such pleiotropic effects ignores the implications of human social structure for life history theory [94]. The overwhelming importance of learned knowledge, social network affiliation, and resource accumulation in human societies, accompanied by extensive cross-generational transfers of knowledge, wealth and social status makes claims that lifespan beyond the age of last reproduction is irrelevant to fitness untenable. Indeed, there is now extensive evidence that women continue making important contributions to the fitness of their direct and indirect descendants long after their direct reproduction has ceased (e.g. [95]). Hence, diseases such as breast cancer that typically occur after age of last reproduction nevertheless can still impose severe selective consequences via effects on parental care and inclusive fitness.

In conclusion, we propose that the $A R$ gene represents a locus of antagonistic pleiotropy in the context of sexual selection and sexual conflict. Our review of previous studies suggests that genes mediating traits likely to be under sexual selection (particularly genes with normal expression patterns in prostate) are associated with the development of cancer (in reproductive tissues in males and females, as well as a wide variety of other tissues), and have frequently been subject to positive selection. This is consistent with the hypothesis that sexual selection and sexually antagonistic coevolution will produce pleiotropic effects that contribute to cancer risk.

\section{Acknowledgments}

K. Summers thanks East Carolina University for a College Research Award that made this research possible, and B. Crespi thanks NSERC for support.

\section{References}

[1] Andersson M. Sexual selection. Princeton (NJ): Princeton University Press; 1994.

[2] Trivers RL. Sexual selection and parental investment. In: Campbell B, editor. Sexual selection and the descent of man. New York: Aldine; 1972.

[3] Williams GC. Pleiotropy, natural selection, and the evolution of senescence. Evolution 1957;11:398-411.

[4] Rice WR, Holland B. The enemies within: intergenomic conflict, interlocus contest evolution (ICE), and the intraspecific red queen. Behav Ecol Sociobiol 1997;41:1-10.

[5] Rice WR, Chippindale AK. Intersexual ontogenetic conflict. J Evol Biol 2001;14:685-93.

[6] Frieberg U, Lew TA, Byrne PG, Rice WR. Assessing the potential for an ongoing arms race within and between the sexes: selection and heritable variation. Evolution 2005;59:1540-51.

[7] Fung KY, Glode LM, Green S, Duncan MW. A comprehensive characterization of the peptide and protein constituents of human seminal fluid. Prostate 2004;61:171-81.

[8] Muehlenbein M, Bribiescas RG. Testosterone-mediated immune functions and male life histories. Am J Hum Biol 2005;17:527-58.

[9] Chapman T. Seminal fluid-mediated fitness traits in Drosophila. Heredity 2001;87:511-21.

[10] Tsaur S, Ting CT, Wu Cl. Sex in Drosophila mauritiana: a very high level of amino acid polymorphism in a male reproductive protein gene, Acp26Aa. Mol Biol Evol 2001;18:22-6.

[11] Swanson W, Vacquier VD. Reproductive protein evolution. Ann Rev Ecol Syst 2002;33:161-79.

[12] Dorus S, Evans PD, Wyckoff GJ, Choi SS, Lahn BT. Rate of molecular evolution of the seminal protein gene SEMG2 correlates with levels of female promiscuity. Nat Genet 2004;36:1326-9.

[13] Mayer JA, Chuong CM, Widelitz R. Rooster feathering, androgenic alopecia, and hormone-dependent tumor growth: what is in common? Differentiation 2004;72:474-88.

[14] Clark N, Swanson WJ. Pervasive adaptive evolution in primate seminal proteins. PLOS Genet 2005;1:335-42.

[15] Ketterson ED, Nolan V. Hormones and life history: an integrative approach. Am Nat 1992;140:S33-62.

[16] Soronen P, Laiti M, Torn S, Harkonen P, Patrikainen L, Li Y, et al. Sex steroid hormone metabolism and prostate cancer. Ster Biochem Mol Biol 2004;92:281-6.

[17] Bribiescas R. Reproductive ecology and life history of the human male. Yrbk Phys Anth 2001;44:148-76.

[18] Crespi BJ, Summers K. Positive selection in the evolution of cancer. Biol Rev Cam Phil Soc 2006.

[19] Taplin ME, Balk SP. Androgen receptor: a key molecule in the progression of prostate cancer to hormone independence. J Cell Biochem 2004;91:483-90.

[20] Ross RK, Pike MC, Coetzee GA, Reichardt JK, Yu MC, Feigelson $\mathrm{H}$, et al. Androgen metabolism and prostate cancer: establishing a model of genetic susceptibility. Cancer Res 1998;58:4497-504.

[21] Gelmann EP. Molecular biology of the androgen receptor. J Clin Oncol 2002;20:3001-15.

[22] Ntais C, Polycarpou A, Tsatsoulis A. Molecular epidemiology of prostate cancer: androgens and polymorphisms in androgen-related genes. Eur J Endocrinol 2003;149:469-77.

[23] Preston-Martin S, Pike MC, Ross RK, Henderson BE. Epidemiologic evidence for the increased cell proliferation 
model of carcinogenesis. Environ Health Perspect 1993;101(Suppl 5):137-8.

[24] Gann PH, Hennekens CH, Ma J, Longcope C, Stampfer MJ. Prospective study of sex hormone levels and risk of prostate cancer. J. Natl. Cancer Inst 1996;88:1118-26.

[25] Chamberlain NL, Driver ED, Miesfeld RL. The length and location of CAG trinucleotide repeats in the androgen receptor $\mathrm{N}$-terminal domain affect transactivation function. Nucleic Acids Res 1994;22:3181-6.

[26] Ingles SA, Ross RK, Yu MC, Irvine RA, La Pera G, Haile RW, et al. Association of prostate cancer risk with genetic polymorphisms in vitamin $D$ receptor and androgen receptor. J Natl Cancer Inst 1997;89:166-70.

[27] Zeegers MP, Kiemeney LA, Nieder AM, Ostrer H. How strong is the association between CAG and GGN repeat length polymorphisms in the androgen receptor gene and prostate cancer risk? Cancer Epidemiol Biomarkers Prev 2004;13:1765-71.

[28] Alvarado C, Beitel LK, Sircar K, Aprikian A, Trifiro M, Gottlieb B. Somatic mosaicism and cancer: a micro-genetic examination into the role of the androgen receptor gene in prostate cancer. Cancer Res 2005;65:8514-8.

[29] Choong CS, Kemppainen JA, Wilson EM. Evolution of the primate androgen receptor: a structural basis for disease. J Mol Evol 1998;47:334-42.

[30] Beilin J, Ball EM, Favaloro JM, Zajac JD. Effect of the androgen receptor CAG repeat polymorphism on transcriptional activity: specificity in prostate and non-prostate cell lines. J Mol Endocrinol 2000;25:85-96.

[31] Irvine RA, Ma H, Yu MC, Ross RK, Stallcup MR, Coetzee GA. Inhibition of p160-mediated coactivation with increasing androgen receptor polyglutamine length. Hum Mol Genet 2000;9:267-74.

[32] Albertelli MA, Scheller A, Brogley M, Robins DM. Replacing the mouse androgen receptor with human alleles demonstrates glutamine tract length-dependent effects on physiology and tumorigenesis in mice. Mol Endocrinol 2006;20:1248-60.

[33] Dowsing AT, Yong EL, Clark M, McLachlan RI, de Kretser DM, Trounson AO. Linkage between male infertility and trinucleotide repeat expansion in the androgen-receptor gene. Lancet 1999;354:640-3.

[34] Lavery R, Houghton JA, Nolan A, Glennon M, Egan D, Maher $M$. CAG repeat length in an infertile male population of irish origin. Genetica 2005;123:295-302.

[35] Canale D, Caglieresi C, Moschini C, Liberati CD, Macchia E, Pinchera A, et al. Androgen receptor polymorphism (CAG repeats) and androgenicity. Clin Endocrinol 2005;63:356-61.

[36] Elzanaty S, Richthoff J, Malm J, Giwercman A. The impact of epididymal and accessory sex gland function on sperm motility. Hum Reprod 2002;17:2904-11.

[37] Giwercman YL, Richthoff J, Lilja H, Anderberg C, Abrahamsson PA, Giwercman A. Androgen receptor CAG repeat length correlates with semen PSA levels in adolescence. Prostate 2004;59:227-33.

[38] Modugno F. Ovarian cancer and polymorphisms in the androgen and progesterone receptor genes: a HuGE review. Am J Epidemiol 2004;159:319-35.

[39] Horie K, Takakura K, Imai K, Liao S, Mori T. Immunohistochemical localization of androgen receptor in the human endometrium, decidua, placenta and pathological conditions of the endometrium. Hum Reprod 1992;7:1461-6.

[40] Ilekis JV, Connor JP, Prins GS, Ferrer K, Niederberger C, Scoccia B. Expression of epidermal growth factor and androgen receptors in ovarian cancer. Gynecol Oncol 1997;66:250-4.
[41] Lau KM, Mok SC, Ho SM. Expression of human estrogen receptor-alpha and -beta, progesterone receptor, and androgen receptor mRNA in normal and malignant ovarian epithelial cells. Proc Natl Acad Sci USA 1999;96:5722-7.

[42] Risch HA. Hormonal etiology of epithelial ovarian cancer, with a hypothesis concerning the role of androgens and progesterone. J Natl Cancer Inst 1998;90:1774-86.

[43] Edmondson RJ, Monaghan JM, Davies BR. The human ovarian surface epithelium is an androgen responsive tissue. Br J Cancer 2002;86:879-85.

[44] Helzlsouer KJ, Alberg AJ, Gordon GB, Longcope C, Bush TL, Hoffman SC, et al. Serum gonadotropins and steroid hormones and the development of ovarian cancer. JAMA 1995;274:1926-30.

[45] Schildkraut JM, Schwingl PJ, Bastos E, Evanoff A, Hughes C. Epithelial ovarian cancer risk among women with polycystic ovary syndrome. Obstet Gynecol 1996;88:554-9.

[46] Silva EG, Tornos C, Fritsche HA, el-Naggar A, Gray K, Ordonez NG, et al. The induction of benign epithelial neoplasms of the ovaries of guinea pigs by testosterone stimulation: a potential animal model. Mod Pathol 1997;10:879-83.

[47] Mahlck CG, Grankvist K, Backstrom T, Kjellgren O. Testosterone, SHBG and albumin in patients with ovarian carcinoma. Acta Obstet Gynecol Scand 1986;65:533-8.

[48] Shaw PA, Rittenberg PV, Brown TJ. Activation of androgen receptor-associated protein 70 (ARA70) mRNA expression in ovarian cancer. Gynecol Oncol 2001;80:132-8.

[49] Evangelou A, Letarte M, Jurisica I, Sultan M, Murphy KJ, Rosen $\mathrm{B}$, et al. Loss of coordinated androgen regulation in nonmalignant ovarian epithelial cells with BRCA1/2 mutations and ovarian cancer cells. Cancer Res 2003;63:2416-24.

[50] Levine DA, Boyd J. The androgen receptor and genetic susceptibility to ovarian cancer: results from a case series. Cancer Res 2001;61:908-11.

[51] Li AJ, Baldwin RL, Karlan BY. Short androgen receptor allele length is a poor prognostic factor in epithelial ovarian carcinoma. Clin Cancer Res 2003;9:3667-73.

[52] Menin C, Banna GL, De Salvo G, Lazzarotto V, De Nicolo A, Agata $S$, et al. Lack of association between androgen receptor CAG polymorphism and familial breast/ovarian cancer. Cancer Lett 2001;168:31-6.

[53] Santarosa M, Bidoli E, Gallo A, Steffan A, Boiocchi M, Viel A. Polymorphic CAG repeat length within the androgen receptor gene: identification of a subgroup of patients with increased risk of ovarian cancer. Oncol Rep 2002;9:639-44.

[54] Suter NM, Malone KE, Daling JR, Doody DR, Ostrander EA. Androgen receptor (CAG)n and (GGC)n polymorphisms and breast cancer risk in a population-based case-control study of young women. Cancer Epidemiol Biomarkers Prev 2003;12:127-35.

[55] Wang W, John EM, Ingles SA. Androgen receptor and prostate-specific antigen gene polymorphisms and breast cancer in African-American women. Cancer Epidemiol Biomarkers Prev 2005;14:2990-4.

[56] Kadouri L, Easton DF, Edwards S, Hubert A, Kote-Jarai Z, Glaser B, et al. CAG and GGC repeat polymorphisms in the androgen receptor gene and breast cancer susceptibility in BRCA1/2 carriers and non-carriers. $\mathrm{Br} \mathrm{J}$ Cancer 2001;85:36-40.

[57] Spurdle AB, Antoniou AC, Duffy DL, Pandeya N, Kelemen L, Chen $X$, et al. The androgen receptor CAG repeat polymorphism and modification of breast cancer risk in BRCA1 and BRCA2 mutation carriers. Breast Cancer Res 2005;7:R176-83. 
[58] Yu H, Bharaj B, Vassilikos EJ, Giai M, Diamandis EP. Shorter CAG repeat length in the androgen receptor gene is associated with more aggressive forms of breast cancer. Breast Cancer Res Treat 2000;59:153-61.

[59] Ferro P, Catalano MG, Dell'Eva R, Fortunati N, Pfeffer U. The androgen receptor CAG repeat: a modifier of carcinogenesis? Mol Cell Endocrinol 2002;193:109-20.

[60] Chippindale AK, Gibson JR, Rice WR. Negative genetic correlation for adult fitness between sexes reveals ontogenetic conflict in Drosophila. Proc Natl Acad Sci USA 2001;98:1671-5.

[61] Yang Z, Bielawski JP. Statistical methods to detect molecular adaptation. Trends Ecol Evol 2000;15: 495-503.

[62] Clements JA, Willemsen NM, Myers SA, Dong Y. The tissue kallikrein family of serine proteases: functional roles in human disease and potential as clinical biomarkers. Crit Rev Clin Lab Sci 2004;41:265-312.

[63] Olsson AY, Lilja H, Lundwall A. Taxon-specific evolution of glandular Kallikrein genes and identification of a progenitor of prostate-specific antigen. Genomics 2004;84:147-56.

[64] Lintula S, Stenman J, Bjartell A, Nordling S, Stenman UH. Relative concentrations of hK2/PSA mRNA in benign and malignant prostatic tissue. Prostate 2005;63:324-9.

[65] Sieh W, Edwards KL, Fitzpatrick AL, Srinouanprachanh SL, Farin FM, Monks SA, et al. Genetic susceptibility to prostate cancer: prostate-specific antigen and its interaction with the androgen receptor (United States). Cancer Causes Control 2006;17:187-97.

[66] Chiang CH, Hong CJ, Chang YH, Chang LS, Chen KK. Human kallikrein-2 gene polymorphism is associated with the occurrence of prostate cancer. J Urol 2005;173: 429-32.

[67] Veveris-Lowe TL, Lawrence MG, Collard RL, Bui L, Herington AC, Nicol DL, et al. Kallikrein 4 (hK4) and prostatespecific antigen (PSA) are associated with the loss of Ecadherin and an epithelial-mesenchymal transition (EMT)like effect in prostate cancer cells. Endocr Relat Cancer 2005;12:631-43.

[68] Borongo CA, Michael IP, Diamandis EP. Human tissue kallikreins: physiologic roles and applications in cancer. Mol Cancer Res 2004;2:257-80.

[69] Yang Z. PAML: a program package for phylogenetic analysis by maximum likelihood. Comput Appl Biosci 1997;13:555-6.

[70] Wilson S, Greer B, Hooper J, Zijlstra A, Walker B, Quigley J, et al. The membrane-anchored serine protease, TMPRSS2, activates PAR-2 in prostate cancer cells. Biochem J 2005;388:967-72.

[71] Lubieniecka JM, Cheteri MK, Stanford JL, Ostrander EA. Met160Val polymorphism in the TRMPSS2 gene and risk of prostate cancer in a population-based case-control study. Prostate 2004;59:357-9.

[72] Lilja H, Abrahamsson PA. Three predominant proteins secreted by the human prostate gland. Prostate 1988;12:29-38.

[73] Baijal-Gupta M, Clarke MW, Finkelman MA, McLachlin CM, Han VK. Prostatic secretory protein (PSP94) expression in human female reproductive tissues, breast and in endometrial cancer cell lines. J Endocrinol 2000;165: 425-33.

[74] Shukeir N, Arakelian A, Chen G, Garde S, Ruiz M, Panchal C, et al. A synthetic 15-mer peptide (PCK3145) derived from prostate secretory protein can reduce tumor growth, experimental skeletal metastases, and malignancy-associated hypercalcemia. Cancer Res 2004;64:5370-7.
[75] Shukeir N, Arakelian A, Kadhim S, Garde S, et al. Prostate secretory protein PSP-94 decreases tumor growth and hypercalcemia of malignancy in a syngenic in vivo model of prostate cancer. Cancer Res 2003;63:2072-8.

[76] Kwong J, Lui K, Chan PS, Ho SM, Wong YC, Xuan JW, et al. Expression study of three secretory proteins (prostatic secretory protein of 94 amino acids, probasin, and seminal vesicle secretion II) in dysplastic and neoplastic rat prostates. Prostate 2003;56:81-97.

[77] Vanaja DK, Cheville JC, Iturria SJ, Young CY. Transcriptional silencing of zinc finger protein 185 identified by expression profiling is associated with prostate cancer progression. Cancer Res 2003;63:3877-82.

[78] Sharief FS, Mohler JL, Sharief Y, Li SS. Expression of human prostatic acid phosphatase and prostate specific antigen genes in neoplastic and benign tissues. Biochem Mol Biol Int 1994;33:567-74.

[79] Tian W, Osawa M, Horiuchi H, Tomita Y. Expression of the prolactin-inducible protein (PIP/GCDFP15) gene in benign epithelium and adenocarcinoma of the prostate. Cancer Sci 2004;5:491-5.

[80] Swinnen JV, Esquenet M, Rosseels J, Claessens F, Rombauts $W$, Heyns $W$, et al. A human gene encoding diazepambinding inhibitor/acy1-CoA-binding protein: transcription and hormonal regulation in the androgen-sensitive human prostatic adenocarcinoma cell line LNCaP. DNA Cell Biol 1996;15:197-208.

[81] Alho H, Kolmer M, Harjuntausta T, Helen P. Increased expression of diazepam binding inhibitor in human brain tumors. Cell Growth Differ 1995:6309-14.

[82] Venturini I, Zeneroli ML, Corsi L, Baraldi C, Ferrarese C, Pecora $\mathrm{N}$, et al. Diazepam binding inhibitor and total cholesterol plasma levels in cirrhosis and hepatocellular carcinoma. Regul Pept 1998;74:31-4.

[83] Clark AG, Glanowski S, Nielsen R, Thomas P, Kejariwa IA, Todd MJ, et al. Inferring nonneutral evolution from humanchimp-mouse orthologous gene trios. Science 2003;302:1960-3.

[84] Schwarze SR, Fu VX, Jarrard DF. Cdc37 enhances proliferation and is necessary for normal human prostate epithelial cell survival. Cancer Res 2003;63:4614-9.

[85] Hofer MD, Kuefer R, Varambally S, Li H, Ma J, Shapiro GI, et al. The role of metastasis-associated protein 1 in prostate cancer progression. Cancer Res 2004;64:825-9.

[86] Schaid DJ. The complex genetic epidemiology of prostate cancer. Hum Mol Genet 2004;13(Spec. No. 1):R103-21.

[87] Agoulnik IU, Vaid A, Bingman WE, Erdeme H, Frolov A, Smith $\mathrm{CL}$, et al. Role of SRC-1 in the promotion of prostate cancer cell growth and tumor progression. Cancer Res 2005;65:7959-67.

[88] Noonan-Wheeler FC, Wu W, Roehl KA, Klim A, Haugen J, Suarez BK, et al. Association of hereditary prostate cancer gene polymorphic variants with sporadic aggressive prostate carcinoma. Prostate 2006;66:49-56.

[89] Powzaniuk M, McElwee-Witmer S, Vogel RL, Hayami T, Rutledge SJ, Chen F, et al. The LATS2/KPM tumor suppressor is a negative regulator of the androgen receptor. Mol Endocrinol 2004;18:2011-23.

[90] Pandini G, Mineo R, Frasca F, Roberts CT, Marcelli M, Vigneri $\mathrm{R}$, et al. Androgens up-regulate the insulin-like growth factor-I receptor in prostate cancer cells. Cancer Res 2005;65:1849-57.

[91] Sangster TA, Lindquist S, Queitsch C. Under cover: causes, effects and implications of Hsp90-mediated genetic capacitance. Bioessays 2004;26:348-62.

[92] Pascale RM, Simile MM, Calvisi DF, Frau M, Muroni MR, Seddaiu MA, et al. Role of HSP90, CDC37, and CRM1 as 
modulators of P16(INK4A) activity in rat liver carcinogenesis and human liver cancer. Hepatology 2005;42:1310-9.

[93] Pepin K, Momose F, Ishida N, Nagata K. Molecular cloning of horse Hsp90 cDNA and its comparative analysis with other vertebrate Hsp90 sequences. J Vet Med Sci 2001;63: 115-24.
[94] Chu CYC, Lee RD. The co-evolution of intergenerational transfers and longevity: an optimal life history approach. Theor Popul Biol 2006;69:193-201.

[95] Lahdenpera M, Lummaa V, Helle S, Tremblay M, Russell AF. Fitness benefits of prolonged post-reproductive lifespan in women. Nature 2004;428:178-81.

Available online at www.sciencedirect.com

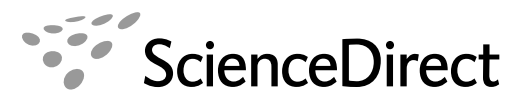

